\title{
Joint Arthroplasties other than the Hip in Solid Organ Transplant Recipients
}

\author{
Arkan S. Sayed-Noor ${ }^{*}$
}

Department of Orthopaedic Surgery, Sundsvall Hospital, S-851 86 Sundsvall, Sweden

\begin{abstract}
Transplantation Surgery has undergone a great development during the last thirty years and the survival of solid organ recipients has increased dramatically. Osteo-articular diseases such as osteoporosis, fractures, avascular bone necrosis and osteoarthritis are relatively common in these patients and joint arthroplasty may be required. The outcome of hip arthroplasty in patients with osteonecrosis of the femoral head after renal transplantation has been studied and documented by many researchers. However, the results of joint arthroplasties other than the hip in solid organs recipients were only infrequently reported in the literature. A systematic review of the English literature was conducted in order to investigate the outcome of joint arthroplasties other than the hip in kidney, liver or heart transplant recipients. Nine pertinent articles including 51 knee arthroplasties, 8 shoulder arthroplasties and 1 ankle arthroplasty were found. These articles reported well to excellent results with a complication rate and spectrum comparable with those reported in nontransplant patients.
\end{abstract}

Keywords: Joint arthroplasty, solid organ transplant, immunosuppression, outcome, complication.

\section{INTRODUCTION}

Solid organ transplantation such as kidney, liver, heart and lung has become the method of choice in treating patients with end-stage failure of these organs. Annually, more than 12000 kidney transplantations, 5000 liver transplantations and 2000 heart transplantations are performed in the United States. The overall long-term survival has apparently improved despite coexisting morbidities, old age and high BMI of the operated patients, higher degree of HLA mismatch and long waiting time [1-7]. This improvement is mainly due to the advancement in careful patient selection, perioperative care, surgical technique and immunosuppressive drugs. However, these patients have increased risk to develop infections and malignancies caused by the required life-long immunosuppressive therapy. Furthermore, the metabolic derangement associated with preoperative renal or hepatic failure as well as post-transplant medications commonly give rise to bone diseases such as osteopenia/osteoporosis, fractures, avascular bone necrosis (AVN) and bone pain. Some of these patients require joint arthroplasty. As the success rate of solid organ transplantation continues to rise, more patients will become candidate to joint replacement surgery. However, concerns still exist regarding the vulnerability of these patients to certain complications such as postoperative infection due to chronic immunosuppression and mechanical implant failure due to poor bone quality.

The results of total hip replacement in renal transplant recipient with AVN of the femoral head were thoroughly discussed by Nowicki and Chaudhary [8]. Their review of literature showed that cemented hip replacement provided

\footnotetext{
*Address correspondence to this author at the Department of Orthopaedic Surgery, Sundsvall Hospital, S-851 86 Sundsvall, Sweden; Tel: +46 379688 466; Fax: +46 60 181751; E-mail: arkansam@yahoo.com
}

good to excellent outcome without significant increment of postoperative infection. The rate of mechanical implant failure was found to be high in young patients and in patients with decreased bony stock. However, porous-coated prostheses were not found to be contra-indicated.

In order to complete the evaluation of the outcome of joint replacement in transplant recipient, We reviewed the literature to study the results of joint replacement surgeries other than the hip in solid organ transplant recipients. We found only few works with markedly few patients.

This might raise the importance of this review article as it assembles the results of these few works so as to give a clearer picture about the outcome of these surgeries.

\section{IMMUNOSUPPRESSIVE THERAPY IN SOLID ORGAN TRANSPLANT RECIPIENTS}

Corticosteroids are still considered as first line armamentarium in the post-transplant immunosuppression. Both high daily doses and pulse doses may be contributed to the high incidence of side effects encountered with these agents. The introduction of Azathioprin, which is a purin synthesis inhibitor, and Cyclosporin $\mathrm{A}$, which is a potent cytotoxic T-cells inhibitor, in early 1980s minimized the need for high corticosteroid doses and improved the overall graft survival reducing the rejection rate. Further advancement was achieved by the discovery and the use of agents such as Tacrolimus which inhibits T-lymphocyte signal transduction and interleukin-2 transcription, and Sirolimus which inhibits the response to interleukin-2 thereby blocking the activation of T- and B-cells.

\section{OSTEO-ARTICULAR DISEASES IN SOLID ORGAN TRANSPLANT RECIPIENTS}

Osteo-articular diseases are common in solid organ transplant recipients $[9,10]$. The underlying pathophysiology is a complex one. Patients with renal or hepatic 
failure, for example, have multi-factorial metabolic bone disease already prior to the transplantation.

Renal osteodystrophy caused by phosphate loss with subsequent hypercalcaemia and hyperparathyroidism is associated with defective mineralization. Vitamin D metabolism is adversely affected in hepatic failure while bone formation is diminished secondary to hyperbilirubinemia and malnutrition. On the other side, acidosis and hypogonadism give rise to high bone turn over. In cardiac failure patients, biomarkers of bone formation and Vitamin D metabolites are lower than in controls while the biomarker of bone resorption is higher [11].

After transplantation, several factors contribute to osteoarticular diseases. Pre-exciting metabolic bone disease, low BMI and muscle mass, postoperative malnutrition and inactivity as well as the immunosuppressive therapy such as high doses of corticosteroids may all lead to poor bone quality and increased fracture risk [9, 12-14]. Moreover, AVN was reported to take place in $3 \%$ to $41 \%$ of renal transplant recipients [15], up to $9 \%$ of liver transplant recipients and $3 \%$ of cardiac transplant recipient $[16,17]$.

\section{MATERIAL AND METHODS}

To address the outlined issue of joint arthroplasties other than the hip in solid organ transplant recipients, we conducted a systematic review of the PubMed (National Library of Medicine and National Institute of Health, USA), Cochrane library and EMBASE archives. We searched for full text articles in English published between 1980 and 2008 using combinations and variations of the following terms: joint replacement/ arthroplasty, organ transplantation, kidney/renal, liver/hepatic, heart/cardiac, outcome and complications. A manual reference check of all retrieved papers and recent reviews was performed to supplement the electronic searches and to identify any additional potentially relevant studies.

Due to the small number of the articles found we chose to include all the papers dealing with the results of joint arthroplasties in solid organ (kidney, liver, heart) transplant recipients regardless of study design, sample size or duration of follow-up.

\section{RESULTS}

The review revealed 9 pertinent studies that met the criteria of inclusion. These included 51 knee arthroplasties, 8 shoulder arthroplasties and 1 ankle arthroplasty. The mean age of patients at the time of arthroplasty operation was 49 years (16-79). The mean time between the transplantation operation and the arthroplasty surgery was 77 months (6294 ) and the mean follow up period for the arthroplasty operations was 60 months (3-202). Follow up was carried out using different outcome indexes, clinical examinations and records concerning the occurrence of various complications. Radiographs were taken whenever indicated to verify the status of the prosthesis examined. All of the included papers reported good to excellent functional outcome. One paper revealed major complications, one of which gave a fatal outcome, while others reported no or minor complications without any drawback of the functional outcome.
Because of the heterogeneity of the obtained data, clinical results were summarized and expressed in Table $\mathbf{1}$ for review by readers.

\section{REVIEW OF THE INCLUDED STUDIES}

Maguire, et al. [18] studied 5 knee arthroplasties with a patellar button performed in patients with kidney transplantation. All patients received perioperative cephalosporines. No complications were reported in this series and the authors found no reason to deny renal transplant patients the benefit of joint arthroplasty. However, no outcome index or information about patients' follow up was provided.

Bradford, et al. [19] reviewed the results in renal transplant recipients of 10 total knee arthroplasties in 6 patients and 3 total shoulder arthroplasties in 2 patients. Most of these patients were young (mean age of 27 years). The indication of the arthroplasties was osteonecrosis presented as pain at mean of 19 months (2-71) posttransplant. The patients received perioperative cephalosporines and corticosteroids when they got their arthroplasties. Of 6 patients presenting for total knee arthroplasty, 3 patients received 4 unicondylar knees while four patients received 6 bicondylar knees. On the other hand, the shoulder arthroplasties performed were of the Neer variety, two including glenoid components. The knee patients were followed up by the Kettlekamp score which improved from 55 to 100 . In the shoulder patients, near normal function of motion with no joint pain were encountered. The authors found that the complications occurred in knee patients were few and minor compared to those affected the hip patients. The shoulder patients showed no complications.

Isono, et al. [20] evaluated 10 cardiac transplant recipients who have had bilateral total hip arthroplasties (9 patients) and bilateral knee arthroplasties (1 patient). The indication for the knee arthroplasties was osteonecrosis of the tibial plateaus. The patient received cephalosporin antibiotics perioperatively. The follow up of this patient revealed good range of motion of the operated knees with no report of any complication i.e. excellent outcome. Papagelopoulos, et al. [21] studied the outcome of joint arthroplasty in a group orthotopic liver transplant recipients. This group included a $48 \mathrm{yr}$ old patient with osteonecrosis of femoral and tibial condyles in one knee and a $39 \mathrm{yr}$ old patient with post-traumatic osteoarthritis (OA) in one knee. These two patients were operated with cemented knee arthroplasties and the outcome was evaluated 3-6 years postoperatively using the Knee Society score. The evaluation showed an excellent outcome (improvement of the score from 45.5 to 94) with no signs of loosening or other complaints. Antibiotics prophylaxis with cephalosporins was used.

The authors believed that despite the high potential for complications, joint arthroplasties in orthotopic liver transplant recipients are considered safe and effective procedures. Tannenbaum, et al. [22] showed high risk of complications in a group renal and hepatic transplant recipients who underwent joint arthroplasties. Among them, there were 3 patients who were operated with knee prosthesis 
Table 1. Summary of the Results of Joint Arthroplasties (other than the Hip) in Solid Organ Transplants

\begin{tabular}{|c|c|c|c|c|c|c|}
\hline Study & $\begin{array}{l}\text { Number of } \\
\text { Arthroplasties }\end{array}$ & $\begin{array}{l}\text { Indication and Time (mo) } \\
\text { Post-Transplant for } \\
\text { Arthroplasty }\end{array}$ & $\begin{array}{l}\text { Mean Age or } \\
\text { Age (yr) at } \\
\text { Arthroplasty }\end{array}$ & $\begin{array}{l}\text { Mean } \\
\text { Follow-Up } \\
(\mathrm{mo})\end{array}$ & Outcome & Complications \\
\hline $\begin{array}{l}\text { Maguire et al. } \\
{[18]}\end{array}$ & 5 knees & $\begin{array}{c}\text { Osteonecrosis } \\
\text { N/A }\end{array}$ & N/A & N/A & N/A & None \\
\hline $\begin{array}{c}\text { Bradford et al. } \\
{[19]}\end{array}$ & $\begin{array}{l}10 \text { knees } \\
\text { (6 patients) } \\
3 \text { shoulder } \\
\text { (2 patients) }\end{array}$ & $\begin{array}{l}\text { Osteonecrosis } \\
42(10-175)\end{array}$ & $34(16-56)$ & $12-108$ & $\begin{array}{c}\text { Kettle-kamp } \\
\text { Knee score: } \\
(37 \rightarrow 72) \\
\text { Shoulder: } \\
\text { No pain } \\
\text { Near normal } \\
\text { function }\end{array}$ & $\begin{array}{l}\text { Conversion of uni- to total } \\
\text { knee prosthesis }(\mathrm{n}=1) \\
\text { Pin extrusion }(\mathrm{n}=1) \\
\text { Stiffness }(\mathrm{n}=1)\end{array}$ \\
\hline $\begin{array}{c}\text { Isono } \\
\text { et al. [20] }\end{array}$ & $\begin{array}{c}2 \text { knees } \\
\text { (1 patient) }\end{array}$ & $\begin{array}{l}\text { Osteonecrosis, } \\
\text { (38) }\end{array}$ & 34 & $34(3-105)$ & N/A & None \\
\hline $\begin{array}{l}\text { Papagel- } \\
\text { opoulos } \\
\text { et al. }[21]\end{array}$ & $\begin{array}{c}2 \text { knees } \\
\text { (2 patients) }\end{array}$ & $\begin{array}{c}\text { Osteonecrosis, (48) } \\
\text { Posttraumatic OA, (39) }\end{array}$ & 39,64 & $36-72$ & $\begin{array}{l}\text { Knee Society } \\
\text { Score } \\
(45.5 \rightarrow 94)\end{array}$ & None \\
\hline $\begin{array}{l}\text { Tannen-baum } \\
\text { et al. }[22]\end{array}$ & $\begin{array}{c}4 \text { knees } \\
\text { (3 patients) }\end{array}$ & $\begin{array}{c}\text { Osteonecrosis, } \\
\text { supracondylar fracture, OA } \\
(36-72)\end{array}$ & $43,45,46,67$ & $12-120$ & $\begin{array}{l}\text { Hospital for } \\
\text { Special } \\
\text { Surgeries } \\
\text { Knee score }\end{array}$ & $\begin{array}{c}\text { PE wear }(\mathrm{n}=1) \\
\text { Infection } \rightarrow \text { death }(\mathrm{n}=1)\end{array}$ \\
\hline $\begin{array}{c}\text { Testa } \\
\text { et al. }[23]\end{array}$ & 4 knees & $\begin{array}{c}\text { N/A } \\
53(39-70)\end{array}$ & N/A & N/A & N/A & None \\
\hline $\begin{array}{c}\text { Levitsky et al. } \\
{[24]}\end{array}$ & $\begin{array}{c}8 \text { knees } \\
\text { (5 patients) } \\
1 \text { ankle } \\
\text { (1 patient) }\end{array}$ & $\begin{array}{l}\text { Osteonecrosis, OA } \\
\qquad(23-74)\end{array}$ & $44(39-59)$ & $50(3-114)$ & N/A & $\begin{array}{l}\text { No major complications } \\
\text { Mild wound bleeding } \\
(\mathrm{n}=1)\end{array}$ \\
\hline $\begin{array}{c}\text { Sperling et al. } \\
{[25]}\end{array}$ & $\begin{array}{l}5 \text { shoulders } \\
\text { (4 patients) }\end{array}$ & $\begin{array}{l}\text { Osteonecrosis, } \\
\text { Malunion, OA, } \\
42(6-71)\end{array}$ & $55(41-79)$ & $65(26-202$ & $\begin{array}{l}\text { Modified } \\
\text { Neer rating }\end{array}$ & $\begin{array}{l}\text { Superior subluxation } \\
\qquad(\mathrm{n}=1) \\
\text { Glenoidal radiolucency } \\
(\mathrm{n}=1)\end{array}$ \\
\hline $\begin{array}{c}\text { Boquet et al. } \\
{[26]}\end{array}$ & $\begin{array}{c}16 \text { knees } \\
\text { (12 patients) }\end{array}$ & $\begin{array}{c}\text { Osteonecrosis, OA, RA } \\
132(10-294)\end{array}$ & $58(32-70)$ & $65(25-107)$ & $\begin{array}{c}\text { Knee Society } \\
\text { Score }=97.1 \\
(93-100)\end{array}$ & Scar necrosis $(n=1)$ \\
\hline
\end{tabular}

Mo: Months, yr: Years, N/A: Not Available, OA: Osteoarthritis, RA: Rheumatoid Arthritis.

(1 patient received double arthroplasties and 2 patients received single arthroplasty). The indications for the arthroplasty operations were osteonecrosis, non union of a supracondylar femoral fracture and OA. All patients received antibiotics prophylaxis with the first generation cephalosporins. The follow up of these patients was carried out using the Hospital for Special Surgery Knee score. The patient with osteonecrosis showed excellent results despite bilateral polyethelene wear of the tibial components. Another patient developed multi-organ failure after enterococcus infection and died. The last patient showed fair results after the knee arthroplasty operation. The authors alarmed for high rate of complications especially infections in this group of patients.

However, this study contained too few patients and the authors agreed that joint arthroplasties can provide an excellent functional outcome. They recommended better preventive measures and high index of suspicion to catch and treat early infections.
In a paper by Testa, et al. [23], the incidence and types of all surgical procedures in a group of liver transplant recipients was investigated and found the orthopaedic procedures to be the second most performed. Among these operations they reported no complications in 4 patients who underwent knee arthroplasties. The authors did not report the functional outcome in these patients.

Levitsky, et al. [24] performed a retrospective analysis on liver transplant recipients who had joint arthroplasty at a single teaching institution between 1986 and 2002. Among the studied group, 8 knees and lankle were included. The indications for the joint arthroplasties were osteonecrosis in 3 knees and 1 ankle and osteoarthritis in 5 knees. No complications were reported during or directly after the operations. The amount of blood loss, length of operation and length of hospital stay were similar to the arthroplasties done in healthy immuno-competent individuals. On long term follow up (50 months, 3-114); no signs of loosening, pain or decreased range of motion were detected. The authors concluded that joint arthroplasties may be safely and 
successfully performed in liver transplant recipients. They recommended larger randomized prospective studies to confirm their results and to make a statistical comparison with arthroplasties performed in healthy individuals.

In a small case series reporting the outcome of 5 shoulder arthroplasties in 4 solid organ transplant recipients ( 2 renal, 1 hepatic and 1 lung), Sperling and Cofield [25] retrospectively reviewed a minimum of 2 years (mean 5.4 years) results using a modified Neer result rating system. The indications of the arthroplasties were osteonecrosis in 3 shoulders (received hemi-arthroplasty), osteoarthritis in 1 (received total shoulder arthroplasty) and malunion in 1 (received total shoulder arthroplasty). Standard antibiotics prophylaxis was given perioperatively. No other preparations were carried out. The authors found 4 excellent results (no or slight pain with at least $140^{\circ}$ active elevation and $45^{\circ}$ external rotation) and one satisfactory result (no to moderate pain with at least $90^{\circ}$ active elevation and $20^{\circ}$ external rotation). No infections or loosening requiring revision surgeries were reported. However, the authors believed that additional follow up was necessary to determine whether the long term results would be comparable to results of patients without transplant surgery.

The most recent paper concerning outcome evaluation of joint arthroplasties in solid organ transplant recipients is published this year in by Boquet, et al. [26]. In this work, the outcome of 16 knee arthroplasties in 12 renal transplant recipients (mean age of 58 years) was evaluated using the Knee Society score and the Knee Society Total Knee Arthroplasty Roentgenographic evaluation. The indications of the arthroplasties were femoral condyle osteonecrosis in 6 knees, tibial plataue osteonecrosis in 1 knee, osteoarthritis in 7 knees and rheumatoid arthritis in 2 knees. The patients were followed up for 65 months (25-107). The authors found excellent clinical results with mean knee score of 97.1 (93$100)$ and mean function score of 87.7 (60-100). The radiological evaluation showed no signs of loosening, osteolysis or malposition of the operated components. This series of patients showed no postoperative infections ot other major complications. One patient developed scar necrosis which warranted surgical repair and 1 patient died 8 years after the arthroplasty operation secondary to mitral valve endocarditis and septicaemia unrelated to the knee surgery. Once again, the authors emphasized the importance of longer term follow up studies to confirm the excellent results found in this report.

\section{CONCLUSION}

Solid organ transplantation is a life-saving operation and transplant patients are unique in many aspects. Many are young and have no previous joint diseases. When these patients develop osteonecrosis with rapid functional deterioration, joint arthroplasty may restore joint function. On the other hand, patients can be elderly and have advanced bone disease. In the later case, joint arthroplasty may be accompanied by increased risk for mechanical failure.

Despite the theoretical risks of high infection rates and inferior bone quality associated with joint arthroplasties in solid organ transplant recipients, the present review shows good to excellent results of knee, shoulder and ankle replacements performed in patients with renal, hepatic, cardiac or lung transplantation. No special perioperative preparations seem necessary. Antibiotics and thrombosis prophylaxis should be given as in standard arthroplasty operations. The relatively young age of patients (mean 49 years) should be considered when choosing the type of implants and the method of fixation. High index of suspicion is essential to catch early infections which should be managed rigorously.

As recommended by most of the papers included in this review, larger prospective studies and long term follow up are needed to determine the safety and outcome of these surgeries in comparison to standard joint arthroplasties done in healthy individuals.

\section{REFERENCES}

[1] Barry JM. Current status of renal transplantation. Patient evaluations and outcomes. Urol Clin N Am 2001; 28(4): 677-86.

[2] Mehrabi A, Fonouni H, Müller SA, Schmidt J. Current concepts in transplant surgery: liver transplantation today. Langenbecks Arch Surg 2008; 393(3): 245-60.

[3] Radovancevic B, Radovancevic R, Vrtovec B, Thomas CD, Frazier $\mathrm{OH}$. Outcomes in patients with low left ventricular ejection fraction after heart transplantation. Eur J Cardiothorac Surg 2003; 23(5): 743-7.

[4] Roberts MS, Angus DC, Bryce CL, Valenta Z, Weissfeld L. Survival after liver transplantation in the United States: a diseasespecific analysis of the UNOS database. Liver Transplant 2004; 10(7): 886-97.

[5] Roussel JC, Baron O, Périgaud C, et al. Outcome of heart transplants 15 to 20 years ago: graft survival, post-transplant morbidity, and risk factors for mortality. J Heart Lung Transplant 2008; 27(5): 486-93.

[6] Verleden GM, Dupont LJ, Van Raemdonck DE, Vos R, Vanaudenaerde BM, Lung Transplant Group. Lung transplantation: a 15-year single-center experience. Clin Transpl 2007; 121-30.

[7] Wolfe RA, Ashby VB, Milford EL, et al. Comparison of mortality in all patients on dialysis, patients on dialysis awaiting transplantation, and recipients of a first cadaveric transplant. N Engl J Med 1999; 341(23): 1725-30.

[8] Nowicki P, Chaudhary H. Total hip replacement in renal transplant patients. J Bone Joint Surg Br 2007; 89(12): 1561-6.

[9] Bia M. Evaluation and management of bone disease and fractures post transplant. Transplant Rev (Orlando) 2008; 22(1): 52-61.

[10] Epstein S. Post-transplantation bone disease: the role of immunosuppressive agents and the skeleton. J Bone Miner Res 1996; 11(1): 1-7.

[11] Schleithoff SS, Zittermann A, Stüttgen B, et al. Low serum levels of intact osteocalcin in patients with congestive heart failure. J Bone Miner Metab 2003; 21(4): 247-52.

[12] Elmsted E. Incidence of skeletal complications in renal graft recipients. Effect of changes in pharmacotherapy. Acta Orthop Scand 1982; 53(6): 853-6.

[13] Guichelaar MM, Schmoll J, Malinchoc M, Hay JE. Fractures and avascular necrosis before and after orthotopic liver transplantation: long-term follow-up and predictive factors. Hepatology 2007; 46 (4): 1198-207.

[14] Ramsey-Goldman R, Dunn JE, Dunlop DD, et al. Increased risk of fracture in patients receiving solid organ transplants. J Bone Miner Res 1999; 14(3): 456-63.

[15] Han D, Kim S, Chang J, Kim S. Avascular necrosis following renal transplantation. Transplant Proc 1998; 30(7): 3034-5.

[16] Bradbury G, Benjamin J, Thompson J, Klees E, Copeland J. Avascular necrosis of bone after cardiac transplantation. Prevalence and relationship to administration and dosage of steroids. J Bone Joint Surg Am 1994; 76(9): 1385-8.

[17] Lieberman JR, Roth KM, Elsissy P, Dorey FJ, Kobashigawa JA Symptomatic osteonecrosis of the hip and knee after cardiac transplantation. J Arthroplasty 2008; 23(1): 90-6.

[18] Maguire WB, Muscio P, Dodd PA. The results of joint replacement surgery in renal transplant patients. Aust N Z J Surg 1981; 51(6): 534-7. 
[19] Bradford DS, Szalapski EW Jr, Sutherland DE, Simmons RL, Najarian JS. Osteonecrosis in the transplant recipient. Surg Gynecol Obstet 1984; 159(4): 328-34.

[20] Isono SS, Woolson ST, Schurman DJ. Total joint arthroplasty for steroid induced osteonecrosis in cardiac transplant patients. Clin Orthop Relat Res 1987; (217): 201-8.

[21] Papagelopoulos PJ, Hay JE, Galanis EC, Morrey BF. Total joint arthroplasty in orthotopic liver transplant recipients. J Arthroplasty 1996; 11(8): 889-92.

[22] Tannenbaum DA, Matthews LS, Grady-Benson JC. Infection around joint replacements in patients who have a renal or liver transplantation. J Bone Joint Surg Am 1997; 79(1): 36-43.
[23] Testa G, Goldstein RM, Toughanipour A, et al. Guidelines for surgical procedures after liver transplantation. Ann Surg 1998; 227(4): 590-9.

[24] Levitsky J, Te HS, Cohen SM. The safety and outcome of joint replacement surgery in liver transplant recipients. Liver Transplant 2003; 9(4): 373-6.

[25] Sperling JW, Cofield RH. Case reports: shoulder arthroplasty in transplant recipients: a report of five cases. Clin Orthop Relat Res 2006; 442: 273-5.

[26] Boquet J, Goffin E, Poilvache P. Outcome of total knee arthroplasties after renal transplantation. Arch Orthop Trauma Surg $2008 ; 128(12): 1345-8$.

(C) Arkan S. Sayed-Noor; Licensee Bentham Open.

This is an open access article licensed under the terms of the Creative Commons Attribution Non-Commercial License (http://creativecommons.org/licenses/by$\mathrm{nc} / 3.0 /$ ) which permits unrestricted, non-commercial use, distribution and reproduction in any medium, provided the work is properly cited. 